\title{
Effect of forage-to-concentrate ratio in dairy cow diets on emission of methane, carbon dioxide, and ammonia, lactation performance, and manure excretion
}

\author{
M. J. Aguerre, ${ }^{\star}$ M. A. Wattiaux, ${ }^{\star 1}$ J. M. Powell, $\dagger$ G. A. Broderick, $†$ and C. Arndt ${ }^{\star}$ \\ *Department of Dairy Science, University of Wisconsin-Madison, Madison 53706 \\ †USDA- ARS, US Dairy Forage Research Center, Madison, WI 53706
}

\section{ABSTRACT}

Holstein cows housed in a modified tie-stall barn were used to determine the effect of feeding diets with different forage-to-concentrate ratios $(\mathrm{F}: \mathrm{C})$ on performance and emission of $\mathrm{CH}_{4}, \mathrm{CO}_{2}$ and manure $\mathrm{NH}_{3}-\mathrm{N}$. Eight multiparous cows (means \pm standard deviation): $620 \pm 68 \mathrm{~kg}$ of body weight; $52 \pm 34 \mathrm{~d}$ in milk and 8 primiparous cows $(546 \pm 38 \mathrm{~kg}$ of body weight; $93 \pm$ $39 \mathrm{~d}$ in milk) were randomly assigned to 1 of 4 airflow controlled chambers, constructed to fit 4 cows each. Chambers were assigned to dietary treatment sequences in a single $4 \times 4$ Latin square design. Dietary treatments, fed as $16.2 \%$ crude protein total mixed rations included the following F:C ratio: 47:53, 54:46, 61:39, and 68:32 [diet dry matter (DM) basis]. Forage consisted of alfalfa silage and corn silage in a 1:1 ratio. Cow performance and emission data were measured on the last $7 \mathrm{~d}$ and the last $4 \mathrm{~d}$, respectively of each 21 -d period. Air samples entering and exiting each chamber were analyzed with a photo-acoustic field gas monitor. In a companion study, fermentation pattern was studied in 8 rumen-cannulated cows. Increasing $\mathrm{F}$ : $\mathrm{C}$ ratio in the diet had no effect on DM intake $(21.1 \pm 1.5 \mathrm{~kg} / \mathrm{d})$, energy-corrected milk (ECM, $37.4 \pm 2.2 \mathrm{~kg} / \mathrm{d}), \mathrm{ECM} /$ DM intake $(1.81 \pm 0.18)$, yield of milk fat, and manure excretion and composition; however, it increased milk fat content linearly by $7 \%$ and decreased linearly true protein, lactose, and solids-not-fat content (by 4 , 1 , and $2 \%$, respectively) and yield (by 10,6 , and $6 \%$, respectively), and milk $\mathrm{N}$-to- $\mathrm{N}$ intake ratio. On average $93 \%$ of the $\mathrm{N}$ consumed by the cows in the chambers was accounted for as milk $\mathrm{N}$, manure $\mathrm{N}$, or emitted $\mathrm{NH}_{3}-\mathrm{N}$. Increasing the $\mathrm{F}$ : $\mathrm{C}$ ratio also increased ruminal $\mathrm{pH}$ linearly and affected concentrations of butyrate and isovalerate quadratically. Increasing the $\mathrm{F}$ : C ratio from 47:53 to 68:32 increased $\mathrm{CH}_{4}$ emission from 538 to 648 $\mathrm{g} /$ cow per day, but had no effect on manure $\mathrm{NH}_{3}-\mathrm{N}$

Received November 16, 2010.

Accepted February 7, 2011.

${ }^{1}$ Corresponding author: wattiaux@wisc.edu emission (14.1 $\pm 3.9 \mathrm{~g} /$ cow per day) and $\mathrm{CO}_{2}$ emission $\left(18,325 \pm 2,241 \mathrm{~g} / \mathrm{cow}\right.$ per day). In this trial, $\mathrm{CH}_{4}$ emission remained constant per unit of neutral detergent fiber intake $\left(1 \mathrm{~g}\right.$ of $\mathrm{CH}_{4}$ was emitted for every $10.3 \mathrm{~g}$ of neutral detergent fiber consumed by the cow), but increased from 14.4 to $18.0 \mathrm{~g} / \mathrm{kg}$ of ECM when the percentage of forage in the diet increased from 47 to $68 \%$. Although the pattern of emission within a day was distinct for each gas, emissions were higher between morning feeding $(0930 \mathrm{~h})$ and afternoon milking $(1600 \mathrm{~h})$ than later in the day. Altering the level of forage within a practical range and rebalancing dietary crude protein with common feeds of the Midwest of the United States had no effects on manure $\mathrm{NH}_{3}-\mathrm{N}$ emission but altered $\mathrm{CH}_{4}$ emission.

Key words: methane, ammonia, forage, dairy cow

\section{INTRODUCTION}

Enteric $\mathrm{CH}_{4}$ emission from ruminant livestock and subsequent emission from stored manure are major contributors to anthropogenic emission of greenhouse gases in many countries (FAO, 2006; EPA, 2009). Livestock manure is also an important source of undesirable atmospheric $\mathrm{NH}_{3}-\mathrm{N}$ (NRC, 2003). Whereas atmospheric $\mathrm{NH}_{3}-\mathrm{N}$ contributes to disturbance of natural ecosystems, $\mathrm{CH}_{4}$ contributes to climate change with an effect equivalent to 25 times that of $\mathrm{CO}_{2}$ over a 100 -yr period (IPCC, 2007). In the United States, livestock manure contributes $50 \%$ of anthropogenic $\mathrm{NH}_{3}-\mathrm{N}$ emission (NRC, 2003) and enteric fermentation is the largest source, contributing $25 \%$ of total anthropogenic $\mathrm{CH}_{4}$ emission (EPA, 2009).

Enteric $\mathrm{CH}_{4}$ production in ruminants is a well-understood process that is closely related to the production of VFA in the rumen (Hungate, 1982; Johnson and Johnson, 1995). The primary substrate for methanogenesis is $\mathrm{H}_{2}$, which is generated mostly during fermentation of plant cell wall carbohydrates to acetate and butyrate (Moss et al., 2000). In contrast, the fermentation of starch and other nonstructural carbohydrates favor propionate production, which serves as a competitive 
pathway for $\mathrm{H}_{2}$ use in the rumen (Benchaar et al., 2001). On the other hand, the emission of $\mathrm{NH}_{3}$ from manure is also well-established and has been associated with the level of urinary urea-N excretion (Paul et al., 1998; James et al., 1999; Monteny et al., 2002). Wattiaux and Karg (2004) found lower concentrations of urea- $\mathrm{N}$ in urine and lower urinary urea- $\mathrm{N}$ in total manure $\mathrm{N}$ when cows were fed alfalfa silage compared with corn silage as the primary forage source in the diet. Broderick (2003) reported increased urinary urea$\mathrm{N}$ excretion with increasing proportion of forage in the diet. Thus, as diets fed to dairy cows in the upper Midwest of the United States typically include 45 to $70 \%$ of forage, mainly from corn silage and alfalfa silage (R. Shaver, Department of Dairy Science, University of Wisconsin-Madison, and M. B. Hall, USDA-ARS, US Dairy Forage Research Center, Madison, WI; personal communication), evidence suggests that altering the source and the level of forage in a dairy cow diet may alter both enteric $\mathrm{CH}_{4}$ and manure $\mathrm{NH}_{3} \mathrm{~N}$ emission under field conditions. Thus, the main objective of this trial was to determine the effect of altering forageto-concentrate $(\mathbf{F}: \mathbf{C})$ ratio in the diet of dairy cows, on production performance, $\mathrm{N}$ partitioning, manure excretion and composition, rumen fermentation pattern, and emission of $\mathrm{CH}_{4}$ and $\mathrm{NH}_{3}-\mathrm{N}$. A second objective was to assess $\mathrm{N}$ mass balance to determine the $\mathrm{N}$ recovery from cows placed in the air-flow controlled chambers.

\section{MATERIALS AND METHODS}

\section{Cows, Diets, and Experimental Design}

Eight multiparous Holstein cows (means \pm SD): $620 \pm 68 \mathrm{~kg}$ of BW; $52 \pm 34$ DIM and 8 primiparous Holstein cows $(546 \pm 38 \mathrm{~kg}$ of $\mathrm{BW} ; 93 \pm 39 \mathrm{DIM})$ were assigned to 1 of 4 air-flow controlled chambers
( 2 primiparous and 2 multiparous cow per chamber) constructed in a modified tie-stall barn. Also, chambers were randomly assigned to one of 4 dietary treatments sequences in a single $4 \times 4$ Latin square design. Treatment sequences within the Latin square were balanced for carryover effects. Cow performance and emission data were measured on the last $7 \mathrm{~d}$ and the last $4 \mathrm{~d}$, respectively of each 21-d period. Individual cow BW was recorded at the beginning of the trial and at the end of each period. Cows were bedded on rubber mats with wheat straw as bedding. Care and handling of the animals were conducted as outlined in the guidelines of the Research Animal and Resource Committee at the University of Wisconsin-Madison.

Ten ingredients (Table 1) were used to construct dietary treatments maintaining alfalfa silage (AS) and corn silage (CS) in a 1:1 ratio in equally spaced increments of 7 units in the proportion of forage, resulting in F:C ratios of 47:53, 54:46, 61:39, and 68:32 (DM basis; Table 2). In addition, a variety of soy-based protein sources were used to keep diets essentially isonitrogenous with recommended levels of RDP and RUP. Each diet was formulated to meet the vitamin and mineral guidelines of NRC (2001). Diets were offered as TMR once daily at $0900 \mathrm{~h}$, allowing for 5 to $10 \%$ orts. Ingredient mix was adjusted based on weekly forage DM analysis.

\section{Feed and Milk Sampling and Analyses}

During the last week of each period, daily samples of approximately $0.5 \mathrm{~kg}$ of silages, high-moisture shelled corn, each TMR, and orts were collected and stored at $-20^{\circ} \mathrm{C}$. Samples of dry ground corn, solvent soybean meal, expeller soybean meal, soy hulls, roasted soybeans and cottonseed were collected on the last day of each period. Weekly composites of individual feed samples were dried at $60^{\circ} \mathrm{C}$ (forced-air oven) for $48 \mathrm{~h}$

Table 1. Chemical composition of dietary ingredients ${ }^{1}$

\begin{tabular}{|c|c|c|c|c|c|c|c|c|c|}
\hline \multirow[b]{2}{*}{ Item } & \multicolumn{9}{|c|}{ Dietary ingredient } \\
\hline & AS & $\mathrm{CS}$ & GCG & HMC & SSBM & ESBM & $\mathrm{RSB}$ & $\mathrm{SH}$ & CTS \\
\hline $\mathrm{DM}(\%)$ & 54.7 & 33.4 & 87.5 & 73.9 & 90.1 & 91.5 & 96.6 & 93.2 & 92.5 \\
\hline Ash (\% DM) & 10.7 & 4.6 & 1.9 & 1.4 & 7.6 & 6.9 & 6.0 & 4.8 & 3.9 \\
\hline $\mathrm{CP}(\% \mathrm{DM})$ & 20.6 & 7.1 & 8.2 & 6.7 & 52.7 & 45.3 & 40.3 & 11.0 & 24.4 \\
\hline NDF (\% DM) & 42.6 & 39.7 & 9.4 & 8.7 & 6.9 & 18.6 & 18.0 & 63.9 & 44.5 \\
\hline $\mathrm{NFC}^{2}(\% \mathrm{DM})$ & 23.9 & 45.4 & 76.6 & 79.6 & 31.7 & 21.8 & 16.1 & 18.0 & 7.8 \\
\hline Starch (\% DM) & 1.4 & 32.6 & 68.9 & 74.1 & 1.3 & 1.6 & 0.8 & 2.5 & 4.6 \\
\hline $\mathrm{DMD}_{30}{ }^{3}(\% \mathrm{DM})$ & 71.4 & 83.0 & - & - & - & - & - & - & - \\
\hline $\mathrm{NDFD}_{30}{ }^{3}(\% \mathrm{NDF})$ & 37.2 & 60.6 & - & - & - & - & - & - & - \\
\hline
\end{tabular}

${ }^{1} \mathrm{AS}=$ alfalfa silage; $\mathrm{CS}=$ corn silage; $\mathrm{GCG}=$ ground corn grain; HMC $=$ high-moisture shelled corn; $\mathrm{SSBM}=$ solvent soybean meal; $\mathrm{ESBM}=$ expeller soybean meal; $\mathrm{RSB}=$ roasted soybeans; $\mathrm{SH}=$ soy hulls; CTS = cottonseed.

${ }^{2} \mathrm{NFC}=100-(\% \mathrm{NDF}-\% \mathrm{CP}+\%$ ether extract $+\%$ ash $)$, using NRC (2001) tabular values for ether extract.

${ }^{3}$ In vitro 30-h DM digestibility (DMD) and NDF digestibility (NDFD; Dairyland Laboratories Inc., Arcadia, WI). 
Table 2. Ingredient and chemical composition of dietary treatments

\begin{tabular}{|c|c|c|c|c|}
\hline \multirow[b]{2}{*}{ Item } & \multicolumn{4}{|c|}{ Forage:concentrate (F:C ratio, DM basis) } \\
\hline & $47: 53$ & $54: 46$ & $61: 39$ & $68: 32$ \\
\hline \multicolumn{5}{|l|}{ Ingredient (\% DM) } \\
\hline Alfalfa silage & 23.5 & 26.9 & 30.5 & 33.9 \\
\hline Corn silage & 23.5 & 26.9 & 30.5 & 33.9 \\
\hline Ground corn grain & 14.5 & 11.7 & 8.5 & 5.7 \\
\hline High-moisture corn & 14.5 & 11.7 & 8.5 & 5.7 \\
\hline Solvent soybean meal & 6.8 & 6.4 & 4.2 & 4.0 \\
\hline Expeller soybean meal ${ }^{1}$ & - & 1.0 & 2.5 & 3.7 \\
\hline Roasted soybeans & 5.0 & 3.3 & 3.0 & 1.0 \\
\hline Soy hulls & 5.0 & 5.0 & 5.0 & 5.0 \\
\hline Cottonseed & 5.0 & 5.0 & 5.0 & 5.0 \\
\hline Vitamins and minerals ${ }^{2}$ & 2.2 & 2.2 & 2.2 & 2.2 \\
\hline \multicolumn{5}{|c|}{ Chemical composition (\% DM) } \\
\hline $\mathrm{DM}(\%)$ & 55.6 & 52.4 & 50.1 & 49.4 \\
\hline $\mathrm{CP}$ & 16.1 & 16.2 & 16.1 & 16.2 \\
\hline Ash & 7.5 & 7.7 & 8.3 & 8.5 \\
\hline NDF & 31.3 & 33.4 & 36.0 & 38.3 \\
\hline Forage NDF & 19.3 & 22.1 & 25.1 & 27.9 \\
\hline Forage NDF (\% NDF) & 68.0 & 72.0 & 76.0 & 79.0 \\
\hline Starch & 29.0 & 26.3 & 22.9 & 20.0 \\
\hline $\mathrm{NFC}^{3}$ & 43.2 & 41.0 & 38.4 & 36.1 \\
\hline $\mathrm{RDP}^{4}$ & 10.9 & 10.9 & 11.0 & 11.0 \\
\hline RUP $^{4}$ & 5.2 & 5.2 & 5.1 & 5.2 \\
\hline $\mathrm{NE}_{\mathrm{L}}^{4}(\mathrm{Mcal} / \mathrm{kg}$ of $\mathrm{DM})$ & 1.62 & 1.59 & 1.58 & 1.54 \\
\hline \multicolumn{5}{|c|}{${ }^{1}$ SoyPlus; West Central Coop. (Ralston, IA). } \\
\hline \multicolumn{5}{|c|}{$\begin{array}{l}{ }^{3} \mathrm{NFC}=100-(\% \mathrm{NDF}+\% \mathrm{CP}+\% \text { ether extract }+\% \text { ash }) \text {, using tabular values for ether extract (NRC, } \\
2001) .\end{array}$} \\
\hline
\end{tabular}

and ground to pass a 1-mm Wiley mill screen (Arthur H. Thomas Co., Philadelphia, PA). Average DMI, on a chamber basis, was computed over the last $7 \mathrm{~d}$ of each period, based on daily individual cow records of TMR offered and refused and the $60^{\circ} \mathrm{C}$ DM contents of the TMR and orts. In addition, DMI was computed on a chamber basis over the $4 \mathrm{~d}$ of gas emission measurements. Ground feed samples were analyzed for total N content (Leco FP-2000 Nitrogen Analyzer, Leco Instruments Inc., St. Joseph, MI), analytical DM at $105^{\circ} \mathrm{C}$ for $24 \mathrm{~h}$, ash content (AOAC, 2006; method 942.05), and NDF content using $\alpha$-amylase (Sigma no. A3306; Sigma Chemical Co., St. Louis, MO) with sodium sulfite and corrected for ash concentration according to Van Soest et al. (1991), adapted for Ankom ${ }^{200}$ Fiber Analyzer (Ankom Technology, Fairport, NY). Nonfiber carbohydrate content was calculated as $100-(\mathrm{NDF}+$ ether extract $+\mathrm{CP}+$ ash), where ether extract was as listed in Table 15.1 of NRC (2001). Dietary ingredients from each period were pooled in a single sample and analyzed commercially for starch content (Dairyland Laboratories, Inc., Arcadia, WI) using wet chemistry analysis (Bach-Knudsen, 1997). In addition, 30-h in vitro ruminal NDF digestibility was determined in the pooled AS and CS samples by the Dairyland Labo- ratories, Inc. Chemical composition of the diets was computed from chemical composition and proportion of feed ingredients in the TMR.

Milk production of individual cows was recorded at each of the 2 daily milkings (0600 and $1600 \mathrm{~h}$ ) throughout the trial and summarized on a chamber basis both for the last $7 \mathrm{~d}$ and the last $4 \mathrm{~d}$ of each period for statistical analysis of performance data and gas emission per unit of feed consumption or milk production, respectively. Milk samples from morning and evening milkings were collected on d 19 and 20 of each period and analyzed for fat, true protein, lactose, SNF and MUN by infrared analysis (AgSource Milk Analysis Laboratory, Menomonie, WI) with a Foss FT6000 (Foss North America Inc., Eden Prairie, MN). The average daily concentration and yield of milk components were computed using morning and evening milk production as weighing factors. The yield of ECM was calculated from the milk energy output (Tyrrell and Reid, 1965) divided by 0.7 Mcal of $\mathrm{NE}_{\mathrm{L}} / \mathrm{kg}$ of milk $\left(\mathrm{NE}_{\mathrm{L}}\right.$ required for $3.5 \% \mathrm{FCM}$ ). Efficiencies of feed conversion were computed for each chamber as the yields of milk and $3.5 \%$ ECM divided by DMI. In addition, efficiency of $\mathrm{N}$ utilization was calculated as milk $\mathrm{N}$ divided by $\mathrm{N}$ intake and as manure $\mathrm{N}$ divided by milk $\mathrm{N}$. 


\section{Emission Measurements}

Chamber Layout. Technical aspects of the chamber design and function have been described by Powell et al. (2007). However, due to several modifications, a brief description of equipment characteristics, operation, and calibration is warranted. Each chamber was $6.0 \mathrm{~m}$ wide $\times 9.1 \mathrm{~m}$ long $\times 2.9 \mathrm{~m}$ high, contained approximately $165 \mathrm{~m}^{3}$ of air space and included floor-to-ceiling retractable curtain walls. Four outlet duct sections were installed $(5.49 \mathrm{~m}$ in length and $30.5 \mathrm{~cm}$ in diameter) that included a 30.5-cm diameter fan and airflow station (Ultraproof AMPS 811-12, Ultratech Industries, Inc., Garner, NC). To facilitate laminar flow through the measuring sensors, the flow station was located within a straight segment of the outlet duct, with length equivalent to 9-duct diameter between the fan and the airflow station and 2 lengths of duct diameter after the airflow station. In addition, the flow station incorporated an airflow straightening section, using a honeycomb grid at its entrance. A similar $(56-\mathrm{cm})$ air flow measuring station (Ultratech AMPS 811-22) was installed in the inlet duct. Airflow stations consisted of stainless steel pitot tubes that continually measured total and partial static pressure. Polyvinyl tubing was used to connect total and static pressure ports to a differential pressure transmitter (Model 264; Setra System, Inc., Boxborough, MA) to obtain the velocity pressure (difference between total pressure and static pressure). Velocity pressures were recorded every $1 \mathrm{~min}$ using a data logger (CR5000; Campbell Scientific, Logan, Utah).

Air velocity $(\mathrm{m} / \mathrm{min})$ was calculated as a function of the velocity pressure $(\mathrm{mb})$ and air density $\left(\mathrm{kg} / \mathrm{m}^{3}\right)$. The density of air was calculated using the Ideal Gas Law and water vapor in the air according to Lefcourt et al. (2001). To account for the effect of water vapor on air density, the virtual temperature $\left(\mathrm{T}_{\mathrm{v}} ; \mathrm{K}\right)$ that dry air would have if its pressure and specific volume were equal to those of a given sample of moist air was calculated as follows:

$$
\mathrm{T}_{\mathrm{v}}=\left(\mathrm{T}_{\mathrm{c}}+273.2\right) /[1-(\mathrm{E} / \mathrm{P}) \times(1-0.622)],
$$

where $\mathrm{T}_{\mathrm{c}}$ is the air temperature $\left({ }^{\circ} \mathrm{C}\right)$; $\mathrm{E}$ is the actual vapor pressure $(\mathrm{mb})$, where $\mathrm{E}=$ fractional relative humidity $(\mathrm{RH}$; ranging from 0 to 1$) \times$ saturation vapor pressure $\left[\mathrm{ES}(\mathrm{mb})\right.$, where $\left.\mathrm{ES}=6.11 \times 10.0^{\left[7.5 \times \mathrm{T}_{\mathrm{c}} /\left(237.7+\mathrm{T}_{\mathrm{c}}\right)\right.}\right]$ ]; and $\mathrm{P}$ is the barometric pressure $(\mathrm{P} ; \mathrm{mb})$.

Air density was calculated with the following equation:

$$
\mathrm{D}=100 \times \mathrm{P} /\left(\mathrm{T}_{\mathrm{v}} \times 287\right)
$$

where $\mathrm{D}$ is the air density $\left(\mathrm{kg} / \mathrm{m}^{3}\right) ; \mathrm{P}$ is the daily average barometric pressure $(\mathrm{mb})$; and $\mathrm{T}_{\mathrm{v}}$ is the virtual temperature $(\mathrm{K})$ from equation [1].

On each sampling day when curtains were lowered, air velocity in the inlet and outlet ducts was calculated with the following equation:

$$
\mathrm{V}=848.2 \times \sqrt{\left(\mathrm{P}_{\mathrm{v}} / \mathrm{D}\right)}
$$

where $\mathrm{V}$ is air velocity $(\mathrm{m} / \mathrm{min}) ; \mathrm{P}_{\mathrm{v}}$ is the average velocity pressure $(\mathrm{mb})$ recorded when curtains were lowered; and $\mathrm{D}$ is the air density $\left(\mathrm{kg} / \mathrm{m}^{3}\right)$ from equation [2].

Volumetric air flow $\left(\mathrm{m}^{3} / \mathrm{min}\right)$ through the inlet and outlet ducts was calculated as the product of the average air velocity $(\mathrm{m} / \mathrm{min})$ and the cross-sectional area of the airflow station $\left(\mathrm{m}^{2}\right)$. Air temperature was measured using a platinum resistance probe (CS500-T; Campbell Scientific) located in the middle of the duct behind the air samplers (see below) and recorded on the same data logger used for velocity pressure measurements.

Air Sampling and Gaseous Flow. Five stainless steel cross-sectional samplers were constructed to sample air from the chambers (one at the inlet and 4 at the outlet ducts). The inlet sampler consisted of 6 round, hollow arms (15.9-mm i.d.) fixed at $60^{\circ}$ angles to a hollow $38.1-\mathrm{mm}$ i.d. $\times 25.4-\mathrm{mm}$ wide central hub to cover the entire circumference of the duct with four 1.30-mm sampling holes at 18.3, 22.8, 24.7, and $27.4 \mathrm{~cm}$ from the hub. The four $29.85-\mathrm{cm}$ diameter outlet samplers consisted of 6 round arms welded onto a center hollow hub (51 $\mathrm{mm}$ in diameter and 38.1-mm wide). On each arm, 4 sampling holes were drilled at 5.84, 9.45, 12.01 , and $14.15 \mathrm{~cm}$ from the hub. Air samples were drawn through Teflon tubing (6.4-mm o.d., 4.8-mm i.d.; Nalgene, Rochester, NY) connected to a Whatman Hepa-Vent Filter (Fischer Scientific, Pittsburgh, PA) and attached to a $63.5-\mathrm{mm}$ hole in the rear of the sampler hub. All tubing was covered with standard polyethylene pipe insulation (12.7-mm i.d.) and heated with self-regulated heat tape (Easy Heat, Rosemont, IL) to prevent condensation inside the sample lines.

Air samples were sequentially drawn from each of the 5 samplers (one inlet and 4 outlets) using a computer-controlled sequencer (Mark 3 Intelligent Sampler; California Analytical Instruments, Orange, CA) and analyzed for $\mathrm{NH}_{3}, \mathrm{CH}_{4}, \mathrm{CO}_{2}$, and $\mathrm{H}_{2} \mathrm{O}$ concentration (parts per million volume, ppmv) with a manufacturedcalibrated photo-acoustic multi-gas monitor (Innova Model 1412; AirTech Instruments, Ballerup, Denmark). As a result, air from each chamber was sampled for 2.5 min every 12 to $13 \mathrm{~min}$ and concentration $\left(\mathrm{g} / \mathrm{m}^{3}\right)$ of 
the measured gases was calculated with the following equation:

$$
\mathrm{G}=\left(\mathrm{C}_{\mathrm{o}}-\mathrm{C}_{\mathrm{i}}\right) \times 1,000 \times \mathrm{MW} / \mathrm{V} \times 1 / 1,000,000,[4]
$$

where $\mathrm{G}$ is the gas concentration in the duct $\left(\mathrm{g} / \mathrm{m}^{3}\right) ; \mathrm{C}_{0}$ is the concentration of the gas in the outlet air (ppmv); $\mathrm{C}_{\mathrm{i}}$ is the concentration of the gas in the inlet air (ppmv); MW is the molecular weight of the gas $(16.04,17.03$, 44.01, $18.02 \mathrm{~g} / \mathrm{mol}$ for $\mathrm{CH}_{4}, \mathrm{NH}_{3}, \mathrm{CO}_{2}$, and $\mathrm{H}_{2} \mathrm{O}$, respectively); and $\mathrm{V}$ is the volume (L) occupied by $1 \mathrm{~mol}$ of gas at the measured air temperature and pressure.

\section{Gas Emission Measurement and Calculation}

On d 18, after cows had returned from the parlor and TMR had been delivered, chamber curtains were lowered and sealed to initiate emission measurements at approximately $0900 \mathrm{~h}$. At $1600 \mathrm{~h}$ measurements were interrupted to allow for evening milking, but were resumed at approximately $1800 \mathrm{~h}$ until $0530 \mathrm{~h}$ the next morning. This protocol was repeated on d 19, 20, and 21 of each period. Gas emitted (g) during each of the 12- to 13-min sampling intervals was calculated as the product of the gas concentration in the outlet air $\left(\mathrm{g} / \mathrm{m}^{3}\right)$ and the volumetric air flow $\left(\mathrm{m}^{3}\right)$. The daily gas emission $(\mathrm{g} / \mathrm{d})$ was calculated by adding up the gas emitted during each sampling interval, omitting the first $30 \mathrm{~min}$ of data collected every time curtains were lowered and sealed (average of $17 \mathrm{~h}$ and $37 \mathrm{~min}$ ) and extrapolating values to a $24-\mathrm{h}$ basis. Within-day variation in $\mathrm{CH}_{4}$ and $\mathrm{NH}_{3}-\mathrm{N}$ emission was assessed by calculating the average emission ( $\mathrm{g} / \mathrm{h}$ per cow) at five 3 -h time period intervals: 0900 to 1200,1300 to 1600,1830 to 2130,2230 to 0130 , and 0200 to $0500 \mathrm{~h}$. Because of a sensor malfunction, gas emission data from period 3 included measurements conducted on d 18 and 19 only.

\section{Manure Collection and Chamber N Recovery}

Starting d 18 of each period, manure collection stainless steel pans $(1.23-\mathrm{m}$ long $\times 0.38-\mathrm{m}$ wide $\times 0.076-\mathrm{m}$ deep) and plastic urine deflectors were placed in each chamber and daily addition of bedding was recorded. Deposited manure and soiled bedding were weighed in 100-L barrels using a bench scale (Ohaus ES Series Bench Scale; Ohaus Co., Pine Brook, NJ) while cows were in the milking parlor. Manure deposited away from the chambers during milking (approximately $1 \mathrm{~h}$ at each milking) was not collected or sampled. However, cows were given ample time to stand up and void themselves before walking away from the chambers. Manure collected from each chamber was mixed, sampled, acidi- fied $\left(60 \%\right.$ sulfuric acid), and stored at $-20^{\circ} \mathrm{C}$. Before acidification, $\mathrm{pH}$ of a deionized water/manure mixture (2:1 ratio) was measured using a calibrated portable $\mathrm{pH}$ meter (Twin pH-meter Model B-213; Spectrum Technologies Inc., Plainfield, IL).

Manure samples were thawed at $5^{\circ} \mathrm{C}$ overnight, composited by chamber and period and lyophilized in a Frezone 12 freeze dryer (Labonco Corporation, Kansas City, MO). Before lyophilization, an acidified manure subsample was extracted with a $2 \mathrm{M} \mathrm{KCl}$ solution (Misselbrook et al., 2005) for total ammoniacal-N (TAN = $\mathrm{NH}_{3}-\mathrm{N}+\mathrm{NH}_{4}{ }^{+}-\mathrm{N}$ ) determination by colorimetric assay (Chaney and Marbach, 1962). Lyophilized manure samples and wheat straw samples (collected on d 21 of each period), were ground through a 1-mm screen and analyzed for absolute DM and total N. Manure DM was calculated as the amount of sample recovered after lyophilization and total $\mathrm{N}$ was measured using the procedure described previously for feed samples. Nitrogen recovery from each chamber was estimated by mass balance with the following equation:

$$
\begin{gathered}
\mathrm{N} \text { recovery }(\%)=[(\text { milk } \mathrm{N}+\text { manure } \\
\mathrm{N}+\mathrm{N} \text { emission }) / \text { intake } \mathrm{N}] \times 100,
\end{gathered}
$$

where milk $\mathrm{N}(\mathrm{g} / \mathrm{d})=$ milk production $(\mathrm{kg} / \mathrm{d}) \times$ milk total $\mathrm{N}(\%) \times 10$; manure $\mathrm{N}(\mathrm{g} / \mathrm{d})=$ collected manure $(\mathrm{kg} / \mathrm{d}) \times$ manure $\mathrm{N}(\%) \times 10$ ] - [bedding DM $(\mathrm{kg} / \mathrm{d}) \times$ bedding $\mathrm{N}(\%$ of $\mathrm{DM}) \times 10] ; \mathrm{N}$ emission $(\mathrm{g} / \mathrm{d})=\mathrm{NH}_{3^{-}}$ $\mathrm{N}$ emissions measured as described above; and intake $\mathrm{N}$ $(\mathrm{g} / \mathrm{d})=\operatorname{DMI}(\mathrm{kg} / \mathrm{d}) \times$ TMR-N $(\%$ of DM $) \times 10$, where TMR-N had been corrected for orts N.

\section{Rumen Fermentation Pattern}

In a simultaneously-conducted companion $4 \times 4$ Latin square trial, 4 lactating primiparous Holstein cows $(597 \pm 49 \mathrm{~kg}$ of BW; $261 \pm 63 \mathrm{DIM})$ and 4 multiparous Holstein cows $(737 \pm 63 \mathrm{~kg}$ of BW; $76 \pm 80 \mathrm{DIM})$, fitted with ruminal cannulas, were used to study ruminal fermentation pattern associated with the dietary treatments. A metal filter probe was used to sample fluid from 5 locations in the rumen to yield a $60-\mathrm{mL}$ composite sample from cows at 0 (pre-feeding), 8 and 16 $\mathrm{h}$ after feeding on $\mathrm{d} 17$ of each period. Rumen $\mathrm{pH}$ was determined immediately after sample collection using a calibrated portable $\mathrm{pH}$ meter (Twin $\mathrm{pH}$-meter Model B-213; Spectrum Technologies Inc.). One subsample of rumen fluid was acidified with $50 \% \mathrm{H}_{2} \mathrm{SO}_{4}$ and frozen until analysis for VFA by GLC (Perkin Elmer Autosystem, Norwalk, CT), as described by Bal et al. (2000), and a second rumen fluid subsample was mixed with 
$50 \%$ TCA and frozen until analysis for $\mathrm{NH}_{3}-\mathrm{N}$ (Chaney and Marbach, 1962).

\section{Statistical Analysis}

In the gas emission trial, the chamber was the experimental unit, but for convenience of data interpretation, all results were expressed on a per-day and per-cow basis. Data was analyzed with the mixed procedure of SAS (SAS Institute, 2004). Dry matter intake, milk yield, milk composition, gaseous emission, and manure excretion and composition data were analyzed with the following model:

$$
\mathrm{Y}_{\mathrm{ijk}}=\mu+\mathrm{C}_{\mathrm{i}}+\mathrm{P}_{\mathrm{j}}+\mathrm{T}_{\mathrm{k}}+\mathrm{e}_{\mathrm{ijk}},
$$

where $Y_{i j k}$ is the dependent variable, $\mu$ is the overall mean, $\mathrm{C}_{\mathrm{i}}$ is the chamber effect (1 to 4$), \mathrm{P}_{\mathrm{j}}$ is the period effect (1 to 4$), \mathrm{T}_{\mathrm{k}}$ is the treatment effect ( 1 to 4 ), and $\mathrm{e}_{\mathrm{ijk}}$ is the residual error. All terms were considered fixed, except for chamber and residual error.

The above model was expanded to include effect of time and interaction between treatment and time to analyze gas emission data as repeated measurements. The spatial power covariance structure was used to fit a time series-type covariance structure in which the correlation decreases as a function of time.

For the companion trial, cow was the experimental unit and the repeated ruminal measurements $\mathrm{pH}, \mathrm{NH}_{4}{ }^{+}-$ $\mathrm{N}$, and VFA were analyzed with the following model:

$$
\begin{aligned}
\mathrm{Y}_{\mathrm{ijklm}} & =\mu+\mathrm{Sq}_{\mathrm{i}}+\mathrm{Co}_{\mathrm{j}}+\mathrm{P}_{\mathrm{k}}+\mathrm{T}_{1}+\mathrm{e} 1_{\mathrm{ijkl}} \\
& +\mathrm{Ti}_{\mathrm{m}}+\mathrm{T}_{1} \times \mathrm{Ti}_{\mathrm{m}}+\mathrm{e} 2_{\mathrm{ijklm}},
\end{aligned}
$$

where $Y_{\mathrm{ijklm}}$ is the dependent variable, $\mu$ is the overall mean, $\mathrm{Sq}_{\mathrm{i}}$ is the square effect (i.e., parity, 1 to 2 ), $\mathrm{Co}_{\mathrm{j}}$ is the cow within square effect ( 1 to 4 ), $\mathrm{P}_{\mathrm{k}}$ is the period effect (1 to 4$), \mathrm{T}_{1}$ is the treatment effect ( 1 to 4$)$, e $1_{\mathrm{ijkl}}$ is the whole-plot error, $\mathrm{Ti}_{\mathrm{m}}$ is the time effect, $\mathrm{T}_{1} \times \mathrm{Ti}_{\mathrm{m}}$ is the interaction effect between treatment and time, and $\mathrm{e} 2_{\mathrm{ijklm}}$ is the subplot error. All terms were considered fixed, except for cow (within square) and the residual error. The first-order autoregressive covariance structure used to fit the models was selected based on the Akaike information criterion of the mixed models of SAS (SAS Institute, 2004).

Pre-planned orthogonal contrasts were used to test for linear and quadratic effects of treatments. In addition, protected least significant differences were used to detect differences among treatments. Significance was declared at $P \leq 0.05$ and tendency at $0.05<P \leq 0.10$. For repeated measurements, treatment differences at individual time points were assessed using the SLICE option when treatment $\times$ time interactions were significant.

\section{RESULTS}

\section{Diets, Feed Intake, and Performance}

Chemical composition of diet ingredients and dietary treatments are reported in Tables 1 and 2. Based on CP and NDF values reported in Table 15.1 of NRC (2001), CS and AS used in this trial would be categorized as normal and mid-mature to mature, respectively. The 30-h NDF digestibilities of CS and AS were 7\% higher and 22\% lower, than the respective 2009 Dairyland laboratory population averages (Dairyland, 2009). Corn silage starch content was slightly higher than the Dairyland laboratory 2009 average (31.0\% of DM; Dairyland, 2009). High-moisture corn, dry corn, solvent and expeller soybean meals, roasted soybeans, soy hulls and cottonseed were similar in composition to values reported in NRC (2001). Dietary CP and predicted RDP and RUP were similar among treatments and averaged $16.2 \%, 11.0$, and $5.2 \%$, respectively (DM basis). In contrast, as $\mathrm{F}: \mathrm{C}$ ratio increased from $47: 53$ to $68: 32$, NDF increased from 31.3 to $38.3 \%$ of dietary DM, forage NDF (\% of NDF) increased from 68 to $79 \%$, and starch decreased from 29 to $20 \%$ of dietary DM. Diet $\mathrm{NE}_{\mathrm{L}}$ computed on the basis of diet composition, feed analyses, and individual cow traits (BW and DIM) and performance (DMI, milk yield, and milk composition) ranged from 1.62 to $1.54 \mathrm{Mcal} / \mathrm{kg}$ of DM.

As shown in Table 3, dietary treatments did not influence (means $\pm \mathrm{SD}) \mathrm{BW}$ change $(-0.07 \pm 0.87 \mathrm{~kg} /$ cow per day), DMI $(21.1 \pm 1.5 \mathrm{~kg} /$ cow per day), DMI as a percentage of BW $(3.68 \pm 0.20), \mathrm{ECM}(37.2 \pm 2.1$ $\mathrm{kg} /$ cow per day), or ECM/DMI $(1.77 \pm 0.15)$. However, as the $\mathrm{F}: \mathrm{C}$ ratio in the diet increased, milk yield and milk/DMI tended to decrease linearly. The increase in $\mathrm{F}: \mathrm{C}$ ratio in the diet resulted in a linear increase in milk fat concentration and MUN, but a linear decrease in the concentration of true protein, lactose, and SNF. Fat yield was not affected by dietary treatments, but the increase in $\mathrm{F}: \mathrm{C}$ ratio in the diet tended to decrease linearly the yield of lactose and decreased linearly the yield of SNF. The yield of true protein was decreased by 8,83 , and $93 \mathrm{~g} / \mathrm{d}$ when cows were fed the diet with 54,61 , and $68 \%$ of forage, respectively, compared with the $47 \%$ forage diet.

\section{Methane and $\mathrm{CO}_{2}$ Emission}

Average temperature, airflow, and relative humidity in the chambers were $27.5 \pm 4.7^{\circ} \mathrm{C}, 2,375 \pm 187 \mathrm{~m}^{3} / \mathrm{h}$, and $60.8 \pm 8.5 \%$, respectively, with an average of 14.4 
Table 3. Effect of forage-to-concentrate (F:C) ratio in the diet on animal performance (per cow basis)

\begin{tabular}{|c|c|c|c|c|c|c|c|}
\hline \multirow[b]{2}{*}{ Item } & \multicolumn{4}{|c|}{$\mathrm{F}: \mathrm{C}$ ratio (DM basis) } & \multirow[b]{2}{*}{ SEM } & \multicolumn{2}{|c|}{$P$-value ${ }^{1}$} \\
\hline & $47: 53$ & $54: 46$ & $61: 39$ & $68: 32$ & & $\mathrm{~L}$ & Q \\
\hline BW change $(\mathrm{kg} / \mathrm{d})$ & -0.13 & 0.07 & 0.05 & -0.26 & 0.28 & 0.77 & 0.40 \\
\hline DMI $(\mathrm{kg} / \mathrm{d})$ & 21.6 & 21.4 & 20.7 & 20.8 & 0.70 & 0.29 & 0.70 \\
\hline DM intake ( $\%$ of BW) & 3.73 & 3.75 & 3.61 & 3.65 & 0.10 & 0.40 & 0.86 \\
\hline Milk $(\mathrm{kg} / \mathrm{d})$ & 38.8 & 38.4 & 36.9 & 36.9 & 1.41 & 0.10 & 0.82 \\
\hline $\operatorname{ECM}^{2}(\mathrm{~kg} / \mathrm{d})$ & 37.7 & 38.3 & 36.2 & 36.6 & 0.97 & 0.16 & 0.87 \\
\hline Milk/DMI ${ }^{3}$ & 1.81 & 1.80 & 1.79 & 1.77 & 0.09 & 0.09 & 0.88 \\
\hline $\mathrm{ECM} / \mathrm{DMI}^{3}$ & 1.76 & 1.80 & 1.75 & 1.76 & 0.06 & 0.58 & 0.49 \\
\hline \multicolumn{8}{|l|}{ Milk composition } \\
\hline Fat $(\%)$ & 3.58 & 3.68 & 3.72 & 3.82 & 0.10 & 0.04 & 0.93 \\
\hline True protein $(\%)$ & $2.73^{\mathrm{a}}$ & $2.71^{\mathrm{ab}}$ & $2.66^{\mathrm{bc}}$ & $2.61^{\mathrm{c}}$ & 0.09 & $<0.01$ & 0.60 \\
\hline Lactose (\%) & 4.96 & 4.92 & 4.92 & 4.89 & 0.07 & 0.02 & 1.00 \\
\hline SNF $(\%)$ & $8.56^{\mathrm{a}}$ & $8.51^{\mathrm{ab}}$ & $8.46^{\mathrm{bc}}$ & $8.38^{\mathrm{c}}$ & 0.13 & $<0.01$ & 0.56 \\
\hline MUN (mg/dL) & 14.2 & 14.3 & 14.8 & 16.1 & 0.31 & 0.07 & 0.36 \\
\hline \multicolumn{8}{|l|}{ Milk components yield } \\
\hline Fat $(\mathrm{kg} / \mathrm{d})$ & 1.39 & 1.45 & 1.37 & 1.41 & 0.04 & 0.87 & 0.66 \\
\hline True protein $(\mathrm{kg} / \mathrm{d})$ & 1.07 & 1.05 & 0.97 & 0.96 & 0.03 & 0.02 & 0.97 \\
\hline Lactose $(\mathrm{kg} / \mathrm{d})$ & 1.92 & 1.89 & 1.81 & 1.80 & 0.06 & 0.06 & 0.82 \\
\hline $\operatorname{SNF}(\mathrm{kg} / \mathrm{d})$ & 3.32 & 3.27 & 3.11 & 3.10 & 0.10 & 0.05 & 0.91 \\
\hline
\end{tabular}

${ }^{a-c}$ Least squares means in the same row with different superscripts differ $(P<0.05)$.

${ }^{1}$ Probability of a linear (L) or quadratic $(\mathrm{Q})$ effect of $\mathrm{F}$ :C ratio level in the diet.

${ }^{2} \mathrm{ECM}$ calculated as milk $\mathrm{NE}_{\mathrm{L}}$ output $(\mathrm{Mcal} / \mathrm{d}) / 0.7 \mathrm{Mcal}$ of $\mathrm{NE}_{\mathrm{L}} / \mathrm{kg}$ of milk, where milk $\mathrm{NE}_{\mathrm{L}}$ output $=$ milk yield, $\mathrm{kg} / \mathrm{d} \times(0.0929 \times$ milk fat $\%+0.0563 \times$ milk protein $\%+0.0395 \times$ milk lactose $\%)$.

${ }^{3}$ Efficiencies calculated as milk (kg/d) or ECM (kg/d) divided by DMI (kg/d).

\pm 2.3 chamber air exchanges per hour. During the trial, variations in these measurements within a chamber and among chambers were relatively small (data not shown).

Table 4 reports $\mathrm{CH}_{4}$ and $\mathrm{CO}_{2}$ emissions expressed as daily amount and per unit of intake and milk production measured during the last $4 \mathrm{~d}$ of each period. No effect of dietary F:C ratio on milk, 3.5\% ECM, DMI, or OM intake (OMI), but NDF intake increased linearly and was $1.1 \mathrm{~kg} / \mathrm{d}$ higher in the diet with $68 \%$ forage compared with the $47 \%$ forage diet. Positive linear responses to increasing levels of dietary forage were observed for daily $\mathrm{CH}_{4}$ emission, and $\mathrm{CH}_{4}$ emission per kilogram of DMI, OMI, milk, and 3.5\% ECM. In contrast, grams of $\mathrm{CH}_{4}$ emitted per kilogram of NDF intake averaged $98.1 \pm 11.3$ and did not differ among dietary treatment. Thus, on average, $1 \mathrm{~g}$ of $\mathrm{CH}_{4}$ was emitted for every $10.3 \mathrm{~g}$ of NDF consumed by the cow. Separation of treatment means indicated that daily $\mathrm{CH}_{4}$ emission was lowest when cows were fed the $47 \%$ forage diet compared with the mean of the other 3 treatments (538 vs. $610 \mathrm{~g} / \mathrm{cow}$ per day). Also $\mathrm{CH}_{4}$ emission per kilogram of DMI, OMI, and milk was lowest when cows were fed the $47 \%$ forage diet, intermediate for the 2 intermediate treatments, and highest when cows were fed the $68 \%$ forage diet. Finally, $\mathrm{CH}_{4}$ emission per kilogram of $3.5 \%$ ECM was lower when cows were fed a diet with $47 \%$ forage compared with 61 or $68 \%$ forage, but not when compared with the $54 \%$ forage diet (Table 4).
In this experiment, dietary $\mathrm{F}: \mathrm{C}$ ratio had no effect on $\mathrm{CO}_{2}$ emission measurements, except for a $4 \%$ increase in $\mathrm{CO}_{2}$ emission per kilogram of OMI when forage in the diet DM increased from 47 to $68 \%$.

\section{Manure Excretion, Ammonia Emission, and Chamber N Recovery}

Table 5 summarized N-related measurements collected during the last $4 \mathrm{~d}$ of each period. The amount of $\mathrm{NH}_{3}-\mathrm{N}$ emitted $(14.1 \pm 3.9 \mathrm{~g} / \mathrm{cow}$ per day) was not influenced by dietary $\mathrm{F}: \mathrm{C}$ ratio and equated on average to $2.8 \%$ of $\mathrm{N}$ intake and $9.1 \%$ of milk $\mathrm{N}$. In other words, $1 \mathrm{~g}$ of $\mathrm{NH}_{3}-\mathrm{N}$ was emitted for every $36.1 \mathrm{~g}$ of $\mathrm{N}$ consumed by the cow and for every $11.1 \mathrm{~g}$ of $\mathrm{N}$ secreted in milk. Dietary treatments did not affect wet manure excretion $(61 \pm 6.0 \mathrm{~kg} / \mathrm{d})$, dry manure excretion $(10.0$ $\pm 1.0 \mathrm{~kg} / \mathrm{d}$ ) or composition, except for a quadratic response in the concentration of TAN in manure. Overall, average $\mathrm{N}$ intake and manure $\mathrm{N}$ were $507 \pm 55$ and 297 $\pm 8 \mathrm{~g} / \mathrm{cow}$ per day, respectively. In contrast, milk N secretion decreased linearly from 164 to $149 \mathrm{~g} / \mathrm{cow}$ per day, milk N/N intake decreased from 32.2 to $29.9 \%$, and manure $\mathrm{N} /$ milk $\mathrm{N}$ tended to increase from 1.75 to 1.99 when cows were fed the diet with the $47: 53$ $\mathrm{F}: \mathrm{C}$ ratio compared with the $68: 32 \mathrm{~F}: \mathrm{C}$ ratio. The $\mathrm{N}$ recovery calculation indicated that, on average, $93 \pm$ $5 \%$ of the $\mathrm{N}$ consumed by the cows in the chambers was accounted for as milk $\mathrm{N}$, manure $\mathrm{N}$, or emitted $\mathrm{NH}_{3}-\mathrm{N}$. 
Table 4. Effect of forage-to-concentrate (F:C) ratio of the diet on cow performance and $\mathrm{CH}_{4}$ and $\mathrm{CO}_{2}$ emission (per cow basis) during the $4 \mathrm{~d}$ of gas emission measurements

\begin{tabular}{|c|c|c|c|c|c|c|c|}
\hline \multirow[b]{2}{*}{ Item } & \multicolumn{4}{|c|}{$\mathrm{F}: \mathrm{C}$ ratio (DM basis) } & \multirow[b]{2}{*}{ SEM } & \multicolumn{2}{|c|}{$P$-value ${ }^{1}$} \\
\hline & $47: 53$ & $54: 46$ & $61: 39$ & $68: 32$ & & $\mathrm{~L}$ & Q \\
\hline DMI $(\mathrm{kg} / \mathrm{d})$ & 20.7 & 21.0 & 20.2 & 20.2 & 0.67 & 0.46 & 0.82 \\
\hline OM intake $(\mathrm{kg} / \mathrm{d})$ & 18.2 & 18.4 & 17.6 & 17.5 & 0.58 & 0.26 & 0.77 \\
\hline NDF intake (kg/d) & $5.4^{\mathrm{c}}$ & $5.9^{\mathrm{bc}}$ & $6.2^{\mathrm{ab}}$ & $6.5^{\mathrm{a}}$ & 0.18 & $<0.01$ & 0.77 \\
\hline Milk yield $(\mathrm{kg} / \mathrm{d})$ & 38.3 & 37.9 & 36.8 & 36.4 & 1.45 & 0.13 & 0.98 \\
\hline $\operatorname{ECM}^{2}(\mathrm{~kg} / \mathrm{d})$ & 37.3 & 37.9 & 36.2 & 36.1 & 0.98 & 0.20 & 0.70 \\
\hline $\mathrm{CH}_{4}(\mathrm{~g} / \mathrm{d})$ & $538^{\mathrm{b}}$ & $597^{\mathrm{ab}}$ & $586^{\mathrm{ab}}$ & $648^{\mathrm{a}}$ & 29.4 & 0.01 & 0.94 \\
\hline $\mathrm{CH}_{4}(\mathrm{~g} / \mathrm{kg}$ of $\mathrm{DMI})$ & $25.9^{\mathrm{c}}$ & $28.2^{\mathrm{b}}$ & $29.1^{\mathrm{b}}$ & $31.9^{\mathrm{a}}$ & 1.21 & $<0.01$ & 0.68 \\
\hline $\mathrm{CH}_{4}(\mathrm{~g} / \mathrm{kg}$ of $\mathrm{OM}$ intake $)$ & $29.5^{\mathrm{c}}$ & $32.4^{\mathrm{b}}$ & $33.5^{\mathrm{b}}$ & $37.1^{\mathrm{a}}$ & 1.37 & $<0.01$ & 0.63 \\
\hline $\mathrm{CH}_{4}(\mathrm{~g} / \mathrm{kg}$ of NDF intake $)$ & 99.2 & 101.0 & 95.6 & 99.4 & 3.83 & 0.52 & 0.56 \\
\hline $\mathrm{CH}_{4}(\mathrm{~g} / \mathrm{kg}$ of milk $)$ & $14.0^{\mathrm{c}}$ & $15.9^{\mathrm{b}}$ & $16.1^{\mathrm{b}}$ & $17.8^{\mathrm{a}}$ & 0.64 & 0.01 & 0.85 \\
\hline $\mathrm{CH}_{4}(\mathrm{~g} / \mathrm{kg}$ of $\mathrm{ECM})$ & $14.4^{\mathrm{c}}$ & $15.8^{\mathrm{bc}}$ & $16.3^{\mathrm{b}}$ & $18.0^{\mathrm{a}}$ & 0.63 & $<0.01$ & 0.78 \\
\hline $\mathrm{CO}_{2}(\mathrm{~g} / \mathrm{d})$ & 18,396 & 18,653 & 17,974 & 18,278 & 804 & 0.72 & 0.97 \\
\hline $\mathrm{CO}_{2}(\mathrm{~g} / \mathrm{kg}$ of $\mathrm{DMI})$ & 889 & 886 & 894 & 902 & 37.3 & 0.35 & 0.60 \\
\hline $\mathrm{CO}_{2}(\mathrm{~g} / \mathrm{kg}$ of $\mathrm{OM}$ intake $)$ & 1,011 & 1,017 & 1,029 & 1,048 & 42.3 & 0.05 & 0.60 \\
\hline $\mathrm{CO}_{2}(\mathrm{~g} / \mathrm{kg}$ of milk $)$ & 479 & 496 & 492 & 501 & 13.9 & 0.21 & 0.70 \\
\hline $\mathrm{CO}_{2}(\mathrm{~g} / \mathrm{kg}$ of $\mathrm{ECM})$ & 491 & 493 & 496 & 502 & 13.4 & 0.53 & 0.84 \\
\hline
\end{tabular}

\section{Variation in Emission Within a Day}

Figure 1a illustrates the pattern of $\mathrm{CH}_{4}$ emission measured in five 3-h periods relative to feeding. Emission was not affected by dietary treatment (data not shown), but was highest in the hours after TMR feeding (30.4 and $29.4 \mathrm{~g} / \mathrm{hr}$ per cow for the periods between 0900 to $1200 \mathrm{~h}$ and 1300 to $1600 \mathrm{~h}$, respectively), decreased in the hours after the afternoon milking (27.0 and $23.5 \mathrm{~g} /$ $\mathrm{hr}$ per cow for the periods between 1830 to $2130 \mathrm{~h}$ and 2230 to $0130 \mathrm{~h}$, respectively), and reached its lowest value before the next morning milking (0200 to 0500 h, $19.4 \mathrm{~g} / \mathrm{hr}$ per cow). Similarly, the pattern of change in $\mathrm{NH}_{3}-\mathrm{N}$ emission during the day was not affected by dietary treatment (data not shown), but varied with time after feeding (Figure 1b). The emission of $\mathrm{NH}_{3}-\mathrm{N}$ increased between the first and the second 3-h period after feeding ( 0.82 vs. $0.92 \mathrm{~g} / \mathrm{hr}$ per cow), but decreased to an average of $0.63 \mathrm{~g} / \mathrm{hr}$ per cow in the last three 3 -h periods of the day.

\section{Rumen Measurements}

Increasing levels of dietary $\mathrm{F}$ : $\mathrm{C}$ ratio increased ruminal $\mathrm{pH}$ linearly and affected the molar proportion of butyrate and isovalerate quadratically, albeit in numerically narrow ranges (Table 6).

\section{DISCUSSION}

\section{Diet, Animal Performance, and Milk Composition}

Due to the positive association between forage NDF and bulk density of the diet, increasing $\mathrm{F}$ : $\mathrm{C}$ ratio gener- ally results in decreased feed intake (Allen, 2000). However, in the present study only a numerical decrease in DMI was observed. Broderick (2003) reported similar results for cows fed diets ranging from 50 to $75 \%$ forage in dietary DM. As it occurred here, the substitution of (corn) starch for (forage) NDF with increasing forage in the diet likely increased the supply of metabolizable protein through greater microbial protein synthesis in the rumen (Valadares et al., 1999; Broderick, 2003). Given the compositional changes across dietary treatments shown in Table 2, our results agreed also with the notion that increasing $\mathrm{F}$ : $\mathrm{C}$ ratio is associated generally with higher milk fat content and a decrease in milk protein content and sometimes yield (Tessmann et al., 1991; Broderick, 2003; Yang and Beauchemin, 2007). Due to the power of the Latin square as an experimental design in combination with preplanned orthogonal contrasts, linear effects were declared significant in spite of small numerical differences. For example, significance was declared for the $7 \%$ increase in milk fat content, and the 1, 4, and $10 \%$ decrease in lactose content, protein content, and protein yield, respectively, as forage in the ration DM increased from 47 to $68 \%$ (Table 3 ).

\section{Methane Emission}

In this experiment, $\mathrm{CH}_{4}$ emission averaged $592 \pm 96$ $\mathrm{g} /$ cow per day, and $28.8 \pm 3.7,15.9 \pm 2.8$ and $16.0 \pm$ $2.7 \mathrm{~g} / \mathrm{kg}$ of DMI, milk, and ECM, respectively. These values were, in general, higher than those recently reported when measured with cows in chambers, which 
Table 5. Effect of forage-to-concentrate (F:C) ratio in the diet on manure excretion, composition, $\mathrm{N}$ balance, and $\mathrm{NH}_{3}-\mathrm{N}$ emission (per cow basis)

\begin{tabular}{|c|c|c|c|c|c|c|c|}
\hline \multirow[b]{2}{*}{ Item } & \multicolumn{4}{|c|}{$\mathrm{F}: \mathrm{C}$ ratio (DM basis) } & \multirow[b]{2}{*}{ SEM } & \multicolumn{2}{|c|}{$P$-value ${ }^{1}$} \\
\hline & $47: 53$ & $54: 46$ & $61: 39$ & $68: 32$ & & $\mathrm{~L}$ & $\mathrm{Q}$ \\
\hline \multicolumn{8}{|l|}{$\mathrm{NH}_{3}$ emission } \\
\hline $\mathrm{NH}_{3}-\mathrm{N}(\mathrm{g} / \mathrm{d})$ & 13.0 & 14.4 & 13.7 & 15.1 & 1.15 & 0.23 & 0.97 \\
\hline $\mathrm{NH}_{3}-\mathrm{N}$ (\% $\mathrm{N}$ intake $)$ & 2.7 & 2.8 & 2.8 & 3.0 & 0.29 & 0.37 & 0.87 \\
\hline $\mathrm{NH}_{3}-\mathrm{N}(\%$ milk $\mathrm{N})$ & 8.1 & 8.9 & 9.1 & 10.2 & 0.82 & 0.11 & 0.81 \\
\hline \multicolumn{8}{|c|}{ Manure excretion and composition } \\
\hline Wet manure ${ }^{2}(\mathrm{~kg} / \mathrm{d})$ & 57.4 & 62.1 & 61.0 & 64.7 & 2.88 & 0.16 & 0.86 \\
\hline Dry manure $^{2}(\mathrm{~kg} / \mathrm{d})$ & 9.3 & 10.4 & 10.0 & 10.3 & 0.43 & 0.26 & 0.42 \\
\hline Manure $\operatorname{TAN}^{3}(\mathrm{~g} / \mathrm{d})$ & 77.9 & 98.9 & 92.8 & 89.7 & 7.78 & 0.36 & 0.12 \\
\hline Manure TAN (g/kg) & 1.32 & 1.54 & 1.50 & 1.37 & 0.12 & 0.81 & 0.07 \\
\hline Manure $\mathrm{pH}$ & 8.28 & 8.16 & 8.20 & 8.24 & 0.11 & 0.84 & 0.40 \\
\hline \multicolumn{8}{|l|}{$\mathrm{N}$ balance } \\
\hline $\mathrm{N}$ intake $(\mathrm{g} / \mathrm{d})$ & 512 & 520 & 498 & 499 & 16.31 & 0.42 & 0.82 \\
\hline Milk $N^{4}(\mathrm{~g} / \mathrm{d})$ & 164 & 162 & 152 & 149 & 4.28 & 0.03 & 0.83 \\
\hline Manure $\mathrm{N}^{5}(\mathrm{~g} / \mathrm{d})$ & 286 & 313 & 292 & 297 & 14.94 & 0.84 & 0.41 \\
\hline $\mathrm{N}$ recovery ${ }^{6}(\% \mathrm{~N}$ intake $)$ & 91 & 94 & 92 & 93 & 1.99 & 0.78 & 0.51 \\
\hline \multicolumn{8}{|l|}{$\mathrm{N}$ utilization efficiency } \\
\hline Milk N/N intake & 0.32 & 0.31 & 0.31 & 0.30 & 0.2 & 0.01 & 0.82 \\
\hline Manure $\mathrm{N} / \mathrm{milk}^{7}$ & 1.75 & 1.93 & 1.92 & 1.99 & 0.09 & 0.09 & 0.54 \\
\hline
\end{tabular}

${ }^{1}$ Probability of a linear (L) or quadratic (Q) effect of F:C ratio level in the diet.

${ }^{2}$ Excluding manure deposited for the approximately $2 \mathrm{~h}$ away from the stalls during milking.

${ }^{3}$ Total ammoniacal-N.

${ }^{4}$ Calculated assuming milk true protein contains $6.38 \% \mathrm{~N}$.

${ }^{5} \mathrm{Fecal}$ and urinary $\mathrm{N}$ that did not volatilize between manure collection events calculated as [manure collected (g/cow per day) $\times$ manure $\mathrm{N}(\%)]$ - [bedding $(\mathrm{g} /$ cow per day $) \times$ bedding $\mathrm{N}(\%)]$.

${ }^{6} \mathrm{~N}$ recovery $(\% \mathrm{~N}$ intake $)=[($ Milk $\mathrm{N}+$ Manure $\mathrm{N}+\mathrm{N}$ emission $) /$ Intake $\mathrm{N}] \times 100$.

${ }^{7}$ Manure N-to-milk $\mathrm{N}$ ratio, where manure $\mathrm{N}$ and milk $\mathrm{N}$ are expressed in grams per cow per day.

ranged from 241 to $459 \mathrm{~g} / \mathrm{d}$, and from 13.4 to $25.3 \mathrm{~g} /$ $\mathrm{kg}$ of DMI and 9.0 to $17.5 \mathrm{~g} / \mathrm{kg}$ of milk (Hindrichsen et al., 2005; Odongo et al., 2007; Beauchemin et al., 2009; Holtshausen et al., 2009). Differences in diet composition, feed quality and animal performance among published trials may explain in part these disparities. For example, the cited studies used $\mathrm{F}$ : $\mathrm{C}$ ratios corresponding to the lower $2 \mathrm{~F}$ : $\mathrm{C}$ ratios of our trial, but did not include diets with $60 \%$ or more forage. Using the sulfur hexafluoride tracer technique, Agle et al. (2010) reported numerically lower ruminal $\mathrm{CH}_{4}$ emission $(\mathrm{g} / \mathrm{h})$ from cows fed a 28:72 compared with 48:52 dietary F:C ratio. In their modeling effort, Benchaar et al. (2001) predicted a decrease in $\mathrm{CH}_{4}$ production per unit of $\mathrm{GE}$ or $\mathrm{DE}$ as the $\mathrm{F}: \mathrm{C}$ ration in the diet decreased from 100:0 to $30: 80$.

Methane production in the rumen is directly associated with the formation of $\mathrm{H}_{2}$ (Janssen, 2010); therefore, $\mathrm{CH}_{4}$ production can be decreased by depriving methanogens of $\mathrm{H}_{2}$. Higher dietary content of fiber increases the production of acetate (an $\mathrm{H}_{2}$-liberating reaction), whereas diets with higher content of starch favor propionate formation (Valadares et al., 1999) and therefore, decrease $\mathrm{H}_{2}$ formation. In the present study, cows fed the 47:53 F:C ratio diet, which was the lowest $\mathrm{NDF}$, highest starch diet, emitted $17 \%$ less $\mathrm{CH}_{4}$ com- pared with cows fed the 68:32 F:C ratio diet, which was the highest NDF, lowest starch diet (Tables 2 and 4). However, the decrease in $\mathrm{CH}_{4}$ emission was not associated with expected changes in ruminal VFA pattern such as a decrease in A:P ratio (Mc Geough et al., 2010). Interestingly, under certain dietary conditions, significant changes in ruminal VFA pattern without measurable changes in $\mathrm{CH}_{4}$ emission have been reported (Beauchemin and McGinn, 2006; Beauchemin et al., 2007). Several possible explanations exist for the lack of relationship between $\mathrm{CH}_{4}$ emission and rumen VFA pattern found here and by others. First, it may be due, in part, to the limitations of experimental protocol in which sampling frequency (spot sampling vs. continuous measurement) and animals (without or with rumen cannulas) are used for each measurement, suggesting that in spite of technical difficulties in doing so, both measurements should be done with relatively similar frequencies and on the same animals. Second, the molar proportions of ruminal VFA do not necessarily represent the proportion in which they were produced (Sutton et al., 2003), but rather the balance between production and absorption. Factors influencing this balance include protozoal population, rumen $\mathrm{pH}$, and rumen absorptive capacity (Dijkstra et al., 1993; Bannink et al., 2008) and possibly level of intake (Robinson 
Table 6. Effect of forage-to-concentrate (F:C) ratio of the diet on concentration of ruminal metabolites

\begin{tabular}{|c|c|c|c|c|c|c|c|}
\hline \multirow[b]{2}{*}{ Item } & \multicolumn{4}{|c|}{$\mathrm{F}: \mathrm{C}$ ratio (DM basis) } & \multirow[b]{2}{*}{ SE } & \multicolumn{2}{|c|}{$P$-value ${ }^{1}$} \\
\hline & $47: 53$ & $54: 46$ & $61: 39$ & $68: 32$ & & $\mathrm{~L}$ & $\mathrm{Q}$ \\
\hline $\mathrm{pH}$ & $6.38^{\mathrm{c}}$ & $6.45^{\mathrm{bc}}$ & $6.55^{\mathrm{ab}}$ & $6.59^{\mathrm{a}}$ & 0.06 & $<0.01$ & 0.59 \\
\hline $\mathrm{NH}_{3}-\mathrm{N}(\mathrm{mg} / \mathrm{dL})$ & 9.84 & 10.1 & 8.1 & 8.1 & 1.00 & 0.13 & 0.94 \\
\hline Total VFA $(\mathrm{m} M)$ & 61.5 & 63.6 & 70.0 & 67.9 & 4.3 & 0.17 & 0.61 \\
\hline \multicolumn{8}{|l|}{ VFA (mol/100 mol) } \\
\hline Acetate & 65.3 & 63.0 & 64.4 & 64.5 & 1.1 & 0.83 & 0.29 \\
\hline Propionate & 20.5 & 21.5 & 20.7 & 20.9 & 1.0 & 0.95 & 0.66 \\
\hline Isobutyrate & 0.94 & 0.93 & 0.87 & 0.87 & 0.05 & 0.13 & 0.97 \\
\hline Butyrate & 10.3 & 11.1 & 11.0 & 10.8 & 0.3 & 0.28 & 0.05 \\
\hline Valerate & 1.56 & 1.56 & 1.39 & 1.43 & 0.1 & 0.28 & 0.89 \\
\hline Isovalerate & $1.42^{\mathrm{b}}$ & $1.87^{\mathrm{a}}$ & $1.63^{\mathrm{ab}}$ & $1.62^{\mathrm{b}}$ & 0.1 & 0.35 & 0.01 \\
\hline $\mathrm{A}: \mathrm{P}^{2}$ & 3.31 & 3.03 & 3.15 & 3.17 & 0.2 & 0.72 & 0.40 \\
\hline
\end{tabular}

${ }^{\mathrm{a}-\mathrm{c}}$ Least squares means in the same row with different superscripts differ $(P<0.05)$.

${ }^{1}$ Probability of a linear (L) or quadratic (Q) effect of F:C ratio level in the diet.

${ }^{2}$ Acetate-to-propionate ratio.

et al., 2010). In summary, although predicting $\mathrm{CH}_{4}$ emission from the stoichiometry of ruminal fermentation (Moss et al., 2000; Benchaar et al., 2001; Kebreab et al., 2009) is highly desirable, our current inability to do so reliably (Robinson et al., 2010) should guide future research toward a more thorough understanding of the underlying fermentation biology associated with a wide range of diets and feeding conditions.

Our results suggested that both daily $\mathrm{CH}_{4}$ emission and $\mathrm{CH}_{4}$ emission per unit of DMI increased with forage in the diet as a result of increased NDF intake. Kasuya and Takahashi (2010) found a positive correlation between NDF intake and daily $\mathrm{CH}_{4}$ emission. In the current trial, forage fiber quality remained constant, and interestingly, so did the $\mathrm{CH}_{4}$ emission per unit of NDF intake. Future work should explore the relationship between $\mathrm{CH}_{4}$ emission and NDF intake or digestible NDF intake and whether these variables could contribute to the prediction of $\mathrm{CH}_{4}$ emission across dietary conditions.

In our trial, $\mathrm{pH}$ was the only ruminal measurement that was linearly associated with the observed linear increase in $\mathrm{CH}_{4}$ emission when the proportion of forage in the diet was increased. van Kessel and Russell (1996) demonstrated that methanogens were $\mathrm{pH}$ sensitive, methanogenesis was $\mathrm{pH}$ dependent, and no $\mathrm{CH}_{4}$ was produced in vitro when recorded $\mathrm{pH}$ values were below 6.0. In addition, the decrease in $\mathrm{CH}_{4}$ production with lower ruminal $\mathrm{pH}$ in vivo may result, in part, from the sensitivity of certain methanogen-harboring ciliate protozoa to low ruminal pH (Finlay et al., 1994; Newbold et al., 1995). In contrast, $\mathrm{CH}_{4}$ emission may have been enhanced in the lower $\mathrm{F}$ : $\mathrm{C}$ ratio diets because protozoal population increased with increased proportion of concentrates in the diet (Franzolin and Dehority, 1996) and grain-adapted rumen had higher populations of
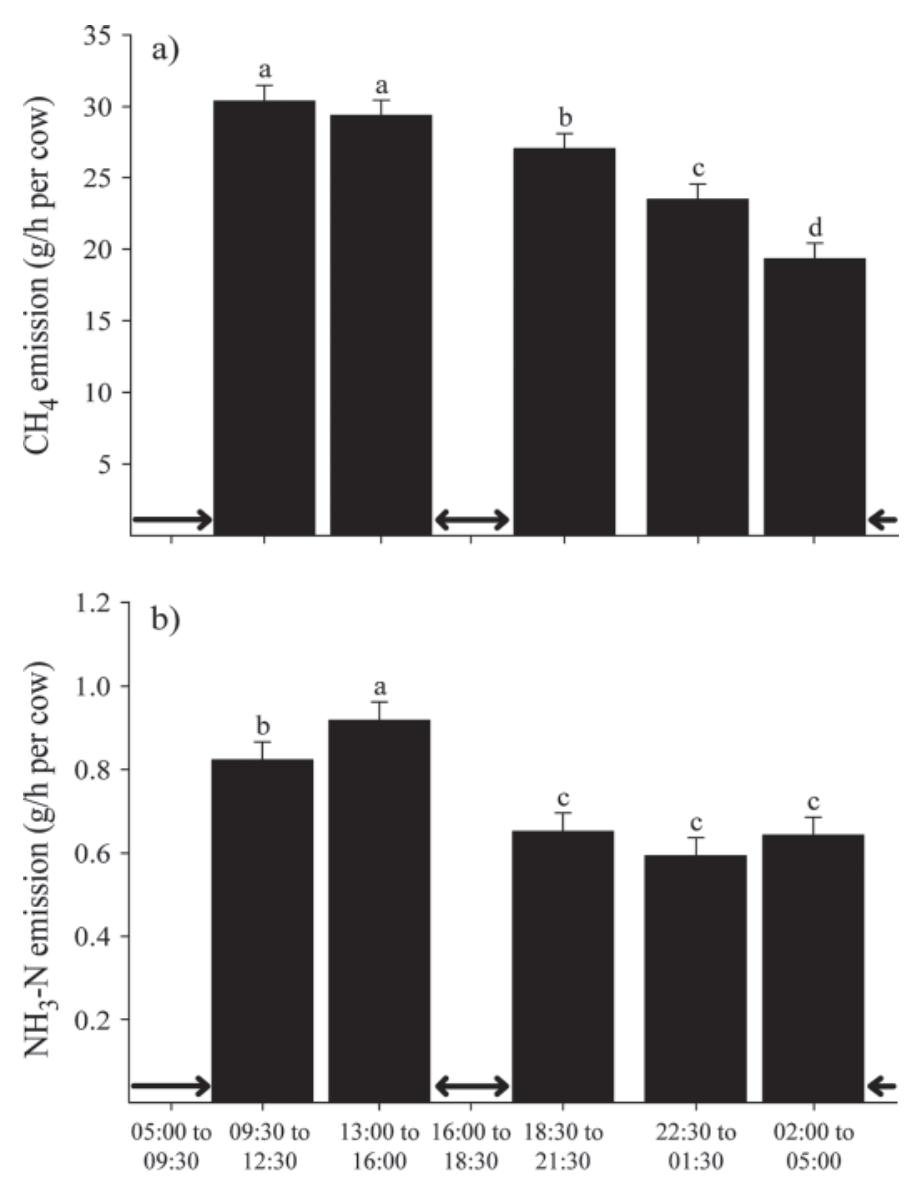

Time (h)

Figure 1. Within-day variation in (a) $\mathrm{CH}_{4}$ and (b) $\mathrm{NH}_{3}-\mathrm{N}$ emission. Horizontal arrows indicate periods of interrupted gas emission measurement due to feeding $(0800 \mathrm{~h})$ and milking (0600 and $1600 \mathrm{~h}$ ). Bars with a different letter differ $(P \leq 0.05)$; vertical bars indicate standard errors of the mean. 
Entodinium and Epidinium ciliate protozoa (Goad et al., 1998) that have been implicated in $\mathrm{CH}_{4}$ production as a result of their symbiotic relationships with methanogenic bacteria (Finlay et al., 1994; Newbold et al., 1995). Although it is unlikely that the small decrease in ruminal $\mathrm{pH}$ observed in the current study had a major influence on methanogenesis, it could not be ignored as a contributing factor.

The higher rate of $\mathrm{CH}_{4}$ emission observed in the hours after feeding in the current study was similar to a pattern reported by others (Kinsman et al., 1995). The data presented by Sun et al. (2008) suggested also that the within-day variation in $\mathrm{CH}_{4}$ emission was associated more with time relative to feeding than with circadian fluctuations.

\section{Ammonia-N Emission and N Mass Balance}

The $\mathrm{NH}_{3}-\mathrm{N}$ emission (14.1 g/cow per day) reported here was similar to values reported for other studies conducted in tie-stall or slatted floor barns (Jungbluth et al. 2001; Powell et al., 2008), but considerably lower than values reported for freestall barns, which average $109 \mathrm{~g} / \mathrm{cow}$ per day when alleys were scrapped (Aguerre et al., 2010) or $182 \mathrm{~g} / \mathrm{cow}$ per day when alleys were flushed (Hollmann et al., 2008). Replacing starch with forage NDF in isonitrogenous diets may increase urea-N excretion in manure. Broderick (2003) observed a $15 \%$ increase in urinary urea- $\mathrm{N}$ excretion when forage level in dietary DM was increased from 50 to $75 \%$. However, in our study, manure $\mathrm{NH}_{3}-\mathrm{N}$ emission was not affected by dietary F:C ratio; maybe because RDP and RUP were maintained carefully within NRC (2001) recommendations. Similarly, Agle et al. (2010) reported no changes in urinary $\mathrm{N}$ excretion and manure $\mathrm{N}$ losses when cows were fed diets with $\mathrm{F}$ :C ratio ranging from 28:72 to 48:52. Dietary forage content had no effect on $\mathrm{NH}_{3}-\mathrm{N}$ emissions from dairy heifers manure measured from freestall barn floors (Lascano et al., 2008) or under laboratory conditions (Zanton and Heinrichs, 2009).

The within-day variation on $\mathrm{NH}_{3}-\mathrm{N}$ emission observed in this trial was similar to the pattern reported by Powell et al. (2008). Manure temperature has been reported as an important factor affecting urease activity and the rate of $\mathrm{NH}_{3}-\mathrm{N}$ emission (Muck, 1982; Monteny et al., 1998) and ambient temperature was found to be a significant contributor to $\mathrm{NH}_{3}-\mathrm{N}$ emission from dairy barns (van Duinkerken et al., 2005). Cooler temperatures during nighttime likely contributed to lower $\mathrm{NH}_{3}-\mathrm{N}$ emissions rates.

In this trial, $\mathrm{N}$ input to the chambers included dietary $\mathrm{N}$ and bedding $\mathrm{N}$ and $\mathrm{N}$ output from the chambers included milk, manure, and $\mathrm{NH}_{3}-\mathrm{N}$ emission. Assuming body $\mathrm{N}$ concentration of $24.7 \mathrm{~g} / \mathrm{kg}$ (Marini and Van
Amburgh, 2003), we calculated that possible change in body $\mathrm{N}$ was negligible $(-1.7 \pm 21 \mathrm{~g} / \mathrm{d})$ and did not differ among treatments.

Even though the effect of $\mathrm{F}$ : $\mathrm{C}$ ratio on nitrous oxide emission was not in the scope of this trial, concentration and flux of this gas was monitored and averaged $0.27 \pm$ $0.13 \mathrm{~g} / \mathrm{cow}$ per day. This emission was lower than the $0.61 \mathrm{~g} /$ cow per day reported by Amon et al. (2001) and accounted for less than $2 \%$ of $\mathrm{NH}_{3}-\mathrm{N}$ emission.

\section{CONCLUSIONS}

In this study, increasing forage level from 47 to $68 \%$ of DM in isonitrogenous diets balanced for RDP and RUP had little effect on performance, manure excretion, or the emissions of $\mathrm{CO}_{2}$ and $\mathrm{NH}_{3}-\mathrm{N}$, but increased $\mathrm{CH}_{4}$ emission. Although daily $\mathrm{CH}_{4}$ emission and $\mathrm{CH}_{4}$ emission per $\mathrm{kg}$ of DMI, milk, and ECM increased with increased forage in the diet, $\mathrm{CH}_{4}$ emission per $\mathrm{kg}$ of NDF intake remained constant. Results failed to confirm that $\mathrm{CH}_{4}$ emission could be predicted from ruminal VFA pattern alone. Although dietary manipulation may be used to abate $\mathrm{CH}_{4}$ emission, systems analysis tools such as life cycle assessment are needed to quantify its effect on milk carbon footprint.

\section{ACKNOWLEDGMENTS}

This research was supported in part by the USDAARS specific cooperative agreement \# 58-3655-7-627 and by USDA-Hatch Multi-State Research Formula fund NE-0144 award number WIS01547. The authors thank Robbin Smith for her assistance in chamber maintenance, calibrations, and conduct of these experiments; Brian Holmes (Department of Biological Systems Engineering, University of Wisconsin-Madison, WI) for his assistance in chamber calibrations; Nancy Betzold and her barn crew for feeding and animal care at the US Dairy Forage Center Research Farm (Prairie du Sac, WI); Wendy Radloff and Mary Becker (US Dairy Forage Research Center, Madison, WI) for assisting with laboratory analyses; and Jacob Finer, Teresa Kaiser, and other UW-Madison students for helping during sample collection and processing.

\section{REFERENCES}

Agle, M., A. N. Hristov, S. Zaman, C. Schneider, P. M. Ndegwa, and V. K. Vaddella. 2010. Effect of dietary concentrate on rumen fermentation, digestibility, and nitrogen losses in dairy cows. J. Dairy Sci. 93:4211-4222.

Aguerre, M. J., M. A. Wattiaux, T. Hunt, and B. R. Larget. 2010. Effect of dietary crude protein on ammonia-N emission measured by herd nitrogen mass balance in a freestall dairy barn managed under farm-like conditions. Animal 4:1390-1400.

Allen, M. S. 2000. Effects of diet on short-term regulation of feed intake by lactating dairy cattle. J. Dairy Sci. 83:1598-1624. 
Amon, B., Th. Amon, J. Boxberger, and Ch. Alt. 2001. Emissions of $\mathrm{NH}_{3}, \mathrm{~N}_{2} \mathrm{O}$ and $\mathrm{CH}_{4}$ from dairy cows housed in a farmyard manure tying stall (housing, manure storage, manure spreading). Nutr. Cycl. Agroecosyst. 60:103-113.

AOAC. 2006. Official Methods of Analysis. Vol. I. 15th ed. Association of Official Analytical Chemists, Arlington, VA.

Bach Knudsen, K. E. 1997. Carbohydrate and lignin contents of plant materials used in animal feeding. Anim. Feed Sci. Technol. 67:319-338.

Bal, M. A., R. D. Shaver, A. G. Jirovec, K. J. Shinners, and J. G. Coors. 2000. Crop processing and chop length of corn silage: Effects on intake, digestion, and milk production by dairy cows. J. Dairy Sci. 83:1264-1273.

Bannink, A., J. France, S. Lopez, W. J. J. Gerrits, E. Kebreab, S. Tamminga, and J. Dijkstra. 2008. Modelling the implications of feeding strategy on rumen fermentation and functioning of the rumen wall. Anim. Feed Sci. Technol. 143:3-26.

Beauchemin, K. A., and S. M. McGinn. 2006. Methane emissions from beef cattle: Effects of fumaric acid, essential oil, and canola oil. J. Anim. Sci. 84:1489-1496.

Beauchemin, K. A., S. M. McGinn, C. Benchaar, and L. Holtshausen. 2009. Crushed sunflower, flax, or canola seeds in lactating dairy cow diets: Effects on methane production, rumen fermentation, and milk production. J. Dairy Sci. 92:2118-2127.

Beauchemin, K. A., S. M. McGinn, T. F. Martinez, and T. A. McAllister. 2007. Use of condensed tannin extract from quebracho trees to reduce methane emissions from cattle. J. Anim. Sci. 85:19901996.

Benchaar, C., C. Pomar, and J. Chiquette. 2001. Evaluation of dietary strategies to reduce methane production in ruminants: A modelling approach. Can. J. Anim. Sci. 81:563-574.

Broderick, G. A. 2003. Effects of varying dietary protein and energy levels on the production of lactating dairy cows. J. Dairy Sci. $86: 1370-1381$.

Chaney, A. L., and E. P. Marbach. 1962. Modified reagents for determination of urea and ammonia. Clin. Chem. 8:130-132.

Dairyland. 2009. Forage summaries. Accessed June 15, 2010. http:// www.dairylandlabs.com/pages/interpretations/forage_2009.php.

Dijkstra, J., H. Boer, J. Van Bruchem, M. Bruining, and S. Tamminga. 1993. Absorption of volatile fatty acids from the rumen of lactating dairy cows as influenced by volatile fatty acid concentration, $\mathrm{pH}$ and rumen liquid volume. Br. J. Nutr. 69:385-396.

EPA. 2009. Inventory of U.S. Greenhouse Gas Emissions and Sinks: 1990-2007. 430-R-09-004. Environmental Protection Agency, Washington, DC.

FAO. 2006. Livestock's long shadow. Environmental issues and options. Accessed June 29, 2010. http://www.fao.org/docrep/010/ a0701e/a0701e00.htm

Finlay, B. J., G. Esteban, K. J. Clarke, A. G. Williams, T. M. Embley, and R. P. Hirt. 1994. Some rumen ciliates have endosymbiotic methanogens. FEMS Microbiol. Lett. 117:157-161.

Franzolin, R., and B. A. Dehority. 1996. Effect of prolonged highconcentrate feeding on ruminal protozoa concentrations. J. Anim. Sci. 74:2803-2809.

Goad, D. W., C. L. Goad, and T. G. Nagaraja. 1998. Ruminal microbial and fermentative changes associated with experimentally induced subacute acidosis in steers. J. Anim. Sci. 76:234-241.

Hindrichsen, I. K., H. R. Wettstein, A. Machmüller, B. Jörg, and M. Kreuzer. 2005. Effect of the carbohydrate composition of feed concentrates on methane emission from dairy cows and their slurry. Environ. Monit. Assess. 107:329-350.

Hollmann, M., K. F. Knowlton, and M. D. Hanigan. 2008. Evaluation of solids, nitrogen, and phosphorus excretion models for lactating dairy cows. J. Dairy Sci. 91:1245-1257.

Holtshausen, L., A. V. Chaves, K. A. Beauchemin, S. M. McGinn, T. A. McAllister, N. E. Odongo, P. R. Cheeke, and C. Benchaar. 2009. Feeding saponin-containing Yucca schidigera and Quillaja saponaria to decrease enteric methane production in dairy cows. J. Dairy Sci. 92:2809-2821.
Hungate, R. E. 1982. Methane formation and cellulose digestion-Biochemical ecology and microbiology of the rumen ecosystem. Cell. Mol. Life Sci. 38:189-192.

IPCC. 2007. Climate change 2007: IPCC Fourth Assessment Report. Cambridge University Press, UK.

James, T., D. Meyer, E. Esparza, E. J. Depeters, and H. Perez-Monti. 1999. Effects of dietary nitrogen manipulation on ammonia volatilization from manure from Holstein heifers. J. Dairy Sci 82:2430-2439.

Janssen, P. H. 2010. Influence of hydrogen on rumen methane formation and fermentation balances through microbial growth kinetics and fermentation thermodynamics. Anim. Feed Sci. Technol. 160:1-22.

Johnson, K. A., and D. E. Johnson. 1995. Methane emissions from cattle. J. Anim. Sci. 73:2483-2492.

Jungbluth, T., E. Hartung, and G. Brose. 2001. Greenhouse gas emissions from animal houses and manure stores. Nutr. Cycl. Agroecosyst. 60:133-145.

Kasuya, H., and J. Takahashi. 2010. Effects of NDF and NFC digestibility on methane emission by lactating Holstein cows fed grass silage-based total mixed ration. Page 100 in Proceedings of the 4th International Conference on Greenhouse Gases and Animal Agriculture, Banff, Canada, October 3-8. E. J. McGeough and S. M. McGinn, ed. Agriculture and Agri-Food Canada, Canada.

Kebreab, E., J. Dijkstra, A. Bannink, and J. France. 2009. Recent advances in modeling nutrient utilization in ruminants. J. Anim. Sci. 87:E111-E122.

Kinsman, R., F. D. Sauer, H. A. Jackson, and M. S. Wolynetz. 1995 Methane and carbon dioxide emissions from dairy cows in full lactation monitored over a six-month period. J. Dairy Sci. 78:27602766 .

Lascano, G. J., G. I. Zanton, M. L. Moody, P. A. Topper, E. F. Wheeler, and A. J. Heinrichs. 2008. Short communication: Effect of changing the ratio of forage to concentrate on ammonia emissions by dairy heifers. J. Dairy Sci. 91:4301-4306.

Lefcourt, A. M., B. Buell, and U. Tasch. 2001. Large environmental chamber: Design and operating characteristics. Appl. Eng. Agric. 17:691-701.

Marini, J. C., and M. E. Van Amburgh. 2003. Nitrogen metabolism and recycling in Holstein heifers. J. Anim. Sci. 81:545-552.

Mc Geough, E. J., P. O'Kiely, K. J. Hart, A. P. Moloney, T. M. Boland, and D. A. Kenny. 2010. Methane emissions, feed intake, performance, digestibility, and rumen fermentation of finishing beef cattle offered whole-crop wheat silages differing in grain content. J. Anim. Sci. 88:2703-2716.

Misselbrook, T. H., J. M. Powell, G. A. Broderick, and J. H. Grabber. 2005. Dietary manipulation in dairy cattle: Laboratory experiments to assess the influence on ammonia emissions. J. Dairy Sci. 88:1765-1777.

Monteny, G. J., D. D. Schulte, A. Elzing, and E. J. J. Lamaker. 1998 A conceptual mechanistic model for ammonia emission from free stall cubicle dairy cow houses. Trans. ASAE 41:193-201.

Monteny, G. J., M. C. J. Smits, G. van Duinkerken, H. Mollenhorst, and I. J. M. de Boer. 2002. Prediction of ammonia emission from dairy barns using feed characteristics Part II: Relation between urinary urea concentration and ammonia emission. J. Dairy Sci. 85:3389-3394.

Moss, A. R., J. P. Jouany, and J. Newbold. 2000. Methane production by ruminants: Its contribution to global warming. Ann. Zootech. 49:231-253.

Muck, R. E. 1982. Urease activity in bovine feces. J. Dairy Sci. 65:2157-2163

National Research Council. 2001. Nutrient Requirements of Dairy Cattle. 7th rev. ed. Natl. Acad. Press, Washington, DC.

National Research Council. 2003. Air emissions from animal feeding operations: Current knowledge, future needs. Natl. Acad. Sci., Washington, DC.

Newbold, C. J., B. Lassalas, and J. P. Jouany. 1995. The importance of methanogens associated with ciliate protozoa in ruminal methane production in vitro. Lett. Appl. Microbiol. 21:230-234. 
Odongo, N. E., R. Bagg, G. Vessie, P. Dick, M. M. Or-Rashid, S. E. Hook, J. T. Gray, E. Kebreab, J. France, and B. W. McBride. 2007. Long-term effects of feeding monensin on methane production in lactating dairy cows. J. Dairy Sci. 90:1781-1788.

Paul, J. W., N. E. Dinn, T. Kannangara, and L. J. Fisher. 1998. Protein content in dairy cattle diets affects ammonia losses and fertilizer nitrogen value. J. Environ. Qual. 27:528-534.

Powell, J. M., G. A. Broderick, and T. H. Misselbrook. 2008. Seasonal diet affects ammonia emissions from tie-stall dairy barns. J. Dairy Sci. 91:857-869.

Powell, J. M., P. R. Cusick, T. H. Misselbrook, and B. J. Holmes. 2007. Design and calibration of chambers for measuring ammonia emissions from tie-stall dairy barns. Trans. ASABE 49:1139-1149.

Robinson, D. L., J. Goopy, and R. S. Hegarty. 2010. Can rumen methane production be predicted from volatile fatty acid concentrations? Anim. Prod. Sci. 50:630-636.

SAS Institute. 2004. SAS/STAT User's Guide. SAS Inst., Inc., Cary, $\mathrm{NC}$

Sun, H., S. L. Trabue, K. Scoggin, W. A. Jackson, Y. Pan, Y. Zhao, I. L. Malkina, J. A. Koziel, and F. M. Mitloehner. 2008. Alcohol, volatile fatty acid, phenol, and methane emissions from dairy cows and fresh waste. J. Environ. Qual. 37:615-622.

Sutton, J. D., M. S. Dhanoa, S. V. Morant, J. France, D. J. Napper, and E. Schuller. 2003. Rates of production of acetate, propionate, and butyrate in the rumen of lactating dairy cows given normal and low-roughage diets. J. Dairy Sci. 86:3620-3633.

Tessmann, N. J., H. D. Radloff, J. Kleinmans, T. R. Dhiman, and L. D. Satter. 1991. Milk production responses to dietary forage:grain ratio. J. Dairy Sci. 74:2696-2707.
Tyrrell, H. F., and J. T. Reid. 1965. Prediction of the energy value of cow's milk. J. Dairy Sci. 48:1215-1223.

Valadares, R. F. D., G. A. Broderick, S. C. Valadares Filho, and M. K. Clayton. 1999. Effect of replacing alfalfa silage with high moisture corn on ruminal protein synthesis estimated from excretion of total purine derivatives. J. Dairy Sci. 82:2686-2696.

van Duinkerken, G., G. André, M. C. J. Smits, G. J. Monteny, and L. B. J. Šebek. 2005. Effect of rumen-degradable protein balance and forage type on bulk milk urea concentration and emission of ammonia from dairy cow houses. J. Dairy Sci. 88:1099-1112.

van Kessel, J. A. S., and J. B. Russell. 1996. The effect of $\mathrm{pH}$ on ruminal methanogenesis. FEMS Microbiol. Ecol. 20:205-210.

Van Soest, P. J., J. B. Robertson, and B. A. Lewis. 1991. Methods for dietary fiber, neutral detergent fiber, and nonstarch polysaccharides in relation to animal nutrition. J. Dairy Sci. 74:3583-3597.

Wattiaux, M. A., and K. L. Karg. 2004. Protein level for alfalfa and corn silage-based diets: II. Nitrogen balance and manure characteristics. J. Dairy Sci. 87:3492-3502.

Yang, W. Z., and K. A. Beauchemin. 2007. Altering physically effective fiber intake through forage proportion and particle length: Chewing and ruminal pH. J. Dairy Sci. 90:2826-2838.

Zanton, G. I., and A. J. Heinrichs. 2009. Digestion and nitrogen utilization in dairy heifers limit-fed low or high forage ration at four levels of nitrogen intake. J. Dairy Sci. 92:2078-2094. 